\title{
The Effect of Discovery Learning Model Assisted with Interactive Learning Video on Students' Metacognitive Awareness
}

\author{
Eka Fitriana Hamsyah* \\ STKIP Pembangunan Indonesia \\ Makassar, Indonesia \\ ekhafitriana89@yahoo.co.id
}

\author{
G Gustina \\ STKIP Pembangunan Indonesia \\ Makassar, Indonesia \\ gustina13082014@gmail.com
}

\author{
Fandi Ahmad \\ STKIP Pembangunan Indonesia \\ Makassar, Indonesia \\ fandi.chem@gmail.com
}

\begin{abstract}
This study aims to determine the effect of the learning model Discovery Learning assisted by interactive learning videos on metacognitive awareness of class XI MA Ummul Mukminin. Various efforts have been made by the teacher to increase students' metacognitive awareness. Metacognitive awareness is related to students' awareness of their abilities. A student knows how best to learn and can know the strengths and weaknesses it has. The design in this study is one group pre-test post-test design. The population in this study were all students of class XI MA Ummul Mukminin Makassar. The sample selection is done by simple random sampling. The stages of the learning model Discovery Learning assisted by interactive learning videos consist of Stimulation, Problem Statement, Collection, Processing, Verification, Generalization. Metacognitive awareness is measured using MAI (Metacognitive Awareness Inventory) which consists of 52 statement items with three dimensions, namely strategic knowledge with 20 statement items, cognitive knowledge with 17 statement items, and self-knowledge with 15 statement items. Hypothesis testing uses the help of the SPSS for Windows 17.0 application through the Paired Sample T-Test. The significance value obtained from the hypothesis test was $p$ $=0.061>=0.05$. This means that there is no significant effect of using the learning model Discovery Learning assisted by interactive learning videos on the metacognitive awareness of class XI students of MA Ummul Mukminin.
\end{abstract}

Keywords-discovery learning, interactive video, metacognitive awareness

\section{INTRODUCTION}

The success in the teaching and learning process in school is influenced by several factors including the selection of learning models, the use of instructional media, and the importance of increasing students' metacognitive awareness. The learning process that is expected to occur is studentcentered learning and not teacher-centered learning as is generally done. Teachers are no longer the only source of information but students are required to be active in finding their learning material. So, learning will be more meaningful.

The learning model of Discovery Learning is one of the models of student-centered learning. Teachers are no longer the only source of information, but students are required to actively seek and find their concepts from the learning material. So that each student can work on and solve their questions related to the material given. This is in line with research conducted by [1] which states that the use of the discovery Learning model with the context of sunflower runs well and contributes positively to the students 'learning outcomes in class VIII SMP Negeri 1 Pagaralam.

Discovery learning which focused on the ability to solve something that relevant to the development of the present situation is required to think about a solution issue that occurs amid society. That is why, discovery-learning needs to be actualized in real life, so students are allowed to respond to more complex life issues [2].

The use of instructional media also plays an important role in the achievement of learning objectives in schools. A teacher must be proficient in using learning media by the characteristics of the material to be given so that students can be motivated to accept the material given. One of the efforts to optimally activate students can be done by displaying interactive learning videos. This interactive learning video can facilitate the teaching and learning process.

According to [3], instructional videos are very appropriate to use for science learning, especially to clearly describe abstract material so that students can easily understand it. However, this is rarely seen by teachers because its use requires assistive devices such as laptops and projectors. According to [4], media plays an important role in the learning process, media is a vehicle for channeling messages from subject matter delivered by a teacher so that students can easily accept what lessons have been delivered. Good media can lead to two-way communication or interactivity.

Moreover, according to the researchers' observations, every class in this school is equipped with a projector, so it is very disadvantageous for a teacher who cannot use the existing facilities. This video contains moving pictures of chemical materials so that students are expected to be motivated to learn and understand existing concepts. Based on research conducted by [5] it is said that the based on video-assisted inquiry modified learning model, students capable discovered, inquired the principle of scientific, experiment and observation, as well as explained the experiment and observation's result so that the students be able to understand the materials which were explained.

The selection of interactive learning videos is included to get rid of the boredom that students may experience. Given that this school is a boarding school, where students are not allowed to use communication tools, watch TV, or listen to the radio. The display of learning videos in class can create a different learning atmosphere from before. 
The syntax of the learning model discovery assisted by interactive learning videos is first stimulation (providing motivation and delivery of learning objectives). Second, problem identification (directs students to make questions related to the material to be studied and concludes in the form of a hypothesis). The third is data collection (displaying interactive learning videos to collect the information needed). The fourth is data processing (providing one or two question numbers relating to the material being discussed). The fifth is verification (matching students' answers and connecting with hypotheses that have been made previously). The sixth is a generalization (making conclusions).

Chemistry is a field of study, it is not only about memorizing but there are formulas, reaction equations, calculations, which make students understand the existing concepts. Salt hydrolysis is a material that requires conceptual understanding. Salt hydrolysis discusses calculating the $\mathrm{pH}$ of acidic, basic, and neutral solutions and the relationship between the hydrolysis constant, water ionization constant, and $\mathrm{H}+$ Concentrations and $\mathrm{OH}-$ both from strong acids, weak acids, strong bases, and weak bases.

According to Nurajizah [6], The process of learning and understanding science has relevance to the level of metacognitive awareness. According to Pantiwati and Husamah [7], Metacognitive awareness constitutes a part of thinking skills to continuously retain and develop. One of the efforts to increase metacognitive awareness is conducting training through lectures integrated into active learning [7]. According to Hindun [8], Metacognitive awareness has been considered as one of the factors within students that determines learning success.

Based on the description above, the researcher is interested in researching by combining learning models and learning media for students' metacognitive awareness. The purpose of this study itself was to determine whether there was a significant effect of using discovery learning models assisted by interactive learning videos on students' metacognitive awareness.

\section{METHODS}

This research is quasi-experimental research that was carried out from February to April 2020. The population in this study were all students of class XI MA Ummul Mukminin. The sample was selected by using simple random sampling. This research was conducted in the odd semester of the 2019-2020 school year with the research design used, namely one group pre-test post-test as shown in the Table I below:

TABLE I. RESEARCH DESIGN

\begin{tabular}{|l|l|l|l|}
\hline Classroom & Pre-test & Action & Post-test \\
\hline A & U1 & C & U2 \\
\hline
\end{tabular}

[9]Note:

$\mathrm{U}_{1}$ : giving metacognitive awareness questionnaire before action

C: Learning in a class by applying learning model discovery assisted by interactive learning video

$\mathrm{U}_{2}$ : giving metacognitive awareness questionnaire after the action

The implementation stages in this study began with giving a pre-test (to find out the value of metacognitive awareness owned by students before participating in-class learning), then the learning process was carried out for five meetings (three initial meetings were held at school as usual and the last two meetings were held from home. via online ZOOM), and the last one is post-test (to find out students' metacognitive awareness after participating in online learning). The questionnaires given before and after learning are the same. Consists of 52 statement items with threedimensional statements about strategic knowledge, cognitive knowledge, and self-knowledge. Statement items were answered using a Likert scale of strongly agree, agree, disagree, and strongly disagree.

Hypothesis testing using analysis Paired-Sample T-test. The value of metacognitive awareness obtained must be tested for normality and homogeneity test as a prerequisite test before testing the hypothesis. The hypothesis in this study is that there is no significant effect of using learning models discovery assisted by interactive learning videos on students 'metacognitive awareness (H0) and there is a significant effect of using learning models discovery assisted by interactive learning videos on students' metacognitive awareness (H1).

\section{RESULTS AND DISCUSSION}

Students' metacognitive awareness can be obtained by using the Metacognitive Awareness Inventory consisting of 52 statement items with 49 positive statement items and three negative statement items. The statement consists of strategy knowledge (20 statement items), cognitive knowledge (17 statement items), and self-knowledge (15 statement items). The form of measuring instrument used is the Likert scale, with four answer criteria, namely strongly agree, agree, disagree, and strongly disagree. The scores from the metacognitive awareness questionnaire that had been filled in by students at the pre-test and post-test were divided into five categories as shown in the Table II below.

TABLE II. COMPARISON OF THE NUMBER OF STUDENTS AT THE PRE-TEST AND POST-TEST

\begin{tabular}{|c|c|c|c|c|c|}
\hline \multirow{2}{*}{$\begin{array}{l}\text { Value } \\
\text { Range }\end{array}$} & \multicolumn{4}{|c|}{$\sum$ Student } & \multirow[b]{2}{*}{ Category } \\
\hline & $\begin{array}{l}\text { Pre- } \\
\text { test }\end{array}$ & $\%$ & $\begin{array}{l}\text { Post- } \\
\text { test }\end{array}$ & $\%$ & \\
\hline $0-20$ & - & - & - & - & MSB \\
\hline $21-40$ & - & - & - & - & $\mathrm{BBB}$ \\
\hline $41-60$ & - & - & - & - & MB \\
\hline $61-80$ & 19 & 86,36 & 15 & 68,18 & BB \\
\hline $81-100$ & 3 & 13,64 & 7 & 31,82 & BSB \\
\hline $\begin{array}{r}\text { Informat } \\
\mathrm{B} \\
\mathrm{B} \\
\mathrm{B} \\
\mathrm{B}\end{array}$ & & $\begin{array}{l}\text { ill Very } \\
\text { t So D } \\
\text { art Dev } \\
\text { ell Dev } \\
\text { ery Wel }\end{array}$ & $\begin{array}{l}\mathrm{k} \\
\text { oped } \\
\text { ing } \\
\text { ed } \\
\text { veloped }\end{array}$ & & \\
\hline
\end{tabular}

The value of metacognitive awareness from pre-test and post-test with the application of the learning model Discovery Learning assisted by learning videos that have increased, remained, and decreased is shown in the table below. 
TABLE III. VALUE OF CONSCIOUSNESS FROM PRE-TEST TO POST-TEST

\begin{tabular}{|l|l|l|}
\hline \multirow{2}{*}{$\begin{array}{l}\text { The value of } \\
\text { metacognitive awareness } \\
\text { from pre-test to post-test }\end{array}$} & $\begin{array}{l}\text { learning model Discovery Learning } \\
\text { assisted by interactive learning } \\
\text { videos }\end{array}$ \\
\cline { 2 - 3 } & $\sum$ Students & \% \\
\hline Increased & 16 & 72,73 \\
\hline Fixed & 2 & 9,09 \\
\hline Decreased & 4 & 18,18 \\
\hline
\end{tabular}

TABLE IV. THE AVERAGE VALUE OF METACOGNITIVE AWARENESS OF CLASS XI STUDENTS OF MA UMMUL MUKMININ MAKASSAR

\begin{tabular}{|l|l|l|l|l|}
\hline Class & $\begin{array}{l}\text { Average } \\
\text { Pre-test } \\
\text { Value }\end{array}$ & $\begin{array}{l}\text { Average } \\
\text { Post-test } \\
\text { Value }\end{array}$ & Category & $\begin{array}{l}\text { Average } \\
\text { Improvement } \\
\text { Value MAI }\end{array}$ \\
\hline A & 70,83 & 72,99 & $\begin{array}{l}\text { Develop } \\
\text { Good }\end{array}$ & 2,16 \\
\hline
\end{tabular}

Furthermore, inferential analysis is carried out through the normality test (to find out whether the data we get is normally distributed or not), the homogeneity test (carried out to find out whether the data we get comes from homogeneous data or not), and hypothesis testing as shown in table V, table VI, and table VII below.
TABLE V. NORMALITY TEST

\begin{tabular}{|l|l|l|}
\hline Data Source & Sig & Description \\
\hline Pre-test & 0,39 & Normal \\
\hline Post-test & 0,67 & Normal \\
\hline \multicolumn{2}{|c|}{$*$ Significance level 0.05}
\end{tabular}

Normality test uses SPSS for windows version 17.0 OneSample Kolmogorov-Smirnov with the test criteria if the significance $>0.05$ then the data is normally distributed, whereas if the significance $<0.05$ then the data is not normally distributed.

TABLE VI. HOMOGENEITY TEST

\begin{tabular}{|l|l|l|}
\hline Test & Sig & Description \\
\hline Levene & 0,88 & Homogen \\
\hline \multicolumn{2}{|c|}{ * Significance level 0.05} \\
\hline
\end{tabular}

Test using SPSS for windows version 17.0 Homogeneity Levene with the test criteria if the significance> 0.05 then the data obtained is homogeneous and if the significance value $<0.05$, the data obtained is not homogeneous.

TABLE VII. HYPOTHESIS TESTING PAIRED SAMPLE T-TEST

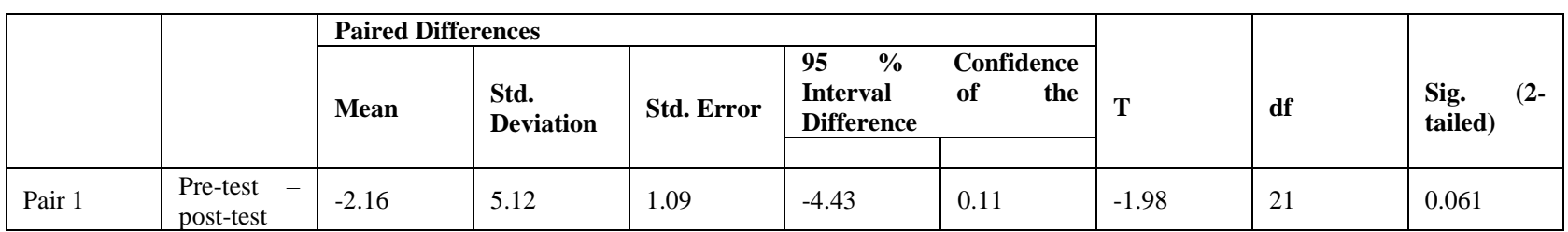

This research was conducted to determine the significant effect of using interactive video-assisted discovery learning models on students' metacognitive awareness. Based on table 4 , it can be seen that 16 students experienced an increase in their scores from pre-test to post-test, 2 students had fixed scores, and four students experienced a decrease in their pretest to post-test scores. Students who experience an increase in the value of metacognitive awareness are influenced by the use of the learning model and media used.

Discovery learning models can train students to learn independently. Students are no longer listeners but active to discover their knowledge. Learning videos also affect increasing students' metacognitive awareness. Video displays can provide a new picture for students who have a characteristic visual learning style. Students come to know that they can understand the material only if they see directly what will be learned rather than just relying on the sense of hearing or just hearing explanations from the teacher.

This is in line with research conducted by [5] video of physics practice as an alternative media to help lecturer and lab assistant when they describe practice step, exercise students to find the resulting, make observation independently, facilitate student's understanding of the practice so as improve student's achievement.

The existence of a new learning model trains students to increase their metacognitive awareness. Whereas for students whose metacognitive awareness remains and decreases, it shows that metacognitive awareness requires a process and will develop gradually and for some other students their metacognitive awareness will not develop [10]. Based on the Paired Sample T-Test, a significance value of 0.061 was obtained. Significance value $>0.05$ means that it accepts H0 and $\mathrm{H} 1$ benchmarks. Accept $\mathrm{H} 0$ means that there is no significant effect using the learning model discovery interactive video-assisted students' metacognitive awareness.

Metacognitive is related to thought processes. In this case metacognitive is associated with the ability to learn. Metacognitive awareness is related to how students learn, students know what is needed in learning, what kind of learning process they want so that learning material can be understood properly. The categories of metacognitive awareness are divided into five categories. The value of students' metacognitive awareness on average was in the well-developed category. Based on table 3, it can be seen that there is an increase in the number of students who are in a very well-developed category. Students with a very welldeveloped category, meaning that these students have been able to manage their learning process (make their study plans), know their weaknesses and strengths and can control, monitor, and control themselves in the learning process. So that students' metacognitive awareness needs to be developed and improved.

Based on the research conducted, it was found that there was no significant effect of using learning model discovery assisted by interactive learning videos on students' 
metacognitive awareness. This is in line with research conducted by [11] which states that the result of the study revealed that there was not the difference of meta-cognitive awareness of student who was taught by using What's My Line of LKS Inductive strategy and the conventional of LKS Inductive strategy on Colloid system subject material with the level of significant 0,15.According to research [12], There is no relationship between critical thinking skills with metacognitive awareness because in theory it is said that critical thinking skills are measuring aspects of students' knowledge at the level of analysis using reason, whereas metacognitive awareness emphasizes student responses by relying on the psychological side so that it is very difficult to find a relationship between thinking skills critical with metacognitive awareness.

This is presumably because students' metacognitive awareness cannot change direction just because of the provision of different learning models in a short time. Although based on the results of the study, many students experienced an increase in the value of metacognitive awareness but were not able to have a significant effect. Learning is carried out only for one material (salt hydrolysis) with 7 meetings. Meeting 1 is a metacognitive awareness questionnaire pre-test, meeting 2, 3, 4 is learning by applying a discovery learning model assisted by interactive video in schools, meeting 5, 6 is learning by applying a discovery learning model assisted by interactive video learning through zoom due to a pandemic causing learning to be done at home, and meeting 7 is a post-test which is also conducted via online (google form).

Another thing that might happen is that students are rushing to complete the questionnaire so that the questionnaire they fill out does not match what they have experienced themselves. Even before filling out the questionnaire, the teacher had told them that this questionnaire had to be filled in according to what they had experienced and it would not affect their scores. Filling in a questionnaire during the post-test which is done online can also be a factor in measuring students' metacognitive awareness that is not optimal.

\section{CONCLUSION}

Based on the results of the research and discussion, it can be concluded that there is no significant effect of using learning models discovery assisted by interactive learning videos on students' metacognitive awareness. Students' metacognitive awareness must be developed and enhanced. The process of increasing metacognitive awareness cannot be done in a short time, so the teacher must be active to develop and increase the metacognitive awareness of each student being taught.

\section{ACKNOWLEDGMENT}

The author would like to thank all those who helped in this research. RistekBRIN, Chairperson of STKIP Pembangunan Indonesia, Head of the Institute for Research and Community Service (LP2M), MA Ummul Mukminin Makassar school, and all students who helped carry out this research.

\section{REFERENCES}

[1] D. Putriani and C. Rahayu, "The effect of discovery learning model using sunflowers in circles on mathematics learning outcomes," Int. J. Trends Math. Educ. Res., Vol. 1, No. 1, p. 22, 2018.

[2] E. Nurcahyo, L. Agung S, and D. Djono, "The implementation of discovery learning model with scientific learning approach to improve students' critical thinking in learning history," Int. J. Multicult. Multireligious Underst., Vol. 5, No. 3, p. 106, 2018.

[3] A. Busyaeri, T. Udin, and A. Zaenudin, "Pengaruh penggunaan video pembelajaran terhadap peningkatan hasil belajar mapel ipa di min kroya cirebon," Al Ibtida J. Pendidik. Guru MI, Vol. 3, No. 1, pp. 116-137, 2016

[4] N. R. Dewi, I. Akhlis, P. P. Ipa, F. Matematika, and P. Alam, "Pengembangan cd interaktif pembelajaran ipaterpadu tema energi dalam kehidupan untuk siswa SMP," USEJ - Unnes Sci. Educ. J., Vol. 2, No. 2, 2013

[5] T. W. Maduretno, A. T. Aziz, and L. Fajri, "The effect of videoassisted inquiry modified learning model on student's achievement on 1st fundamental physics practice," Int. J. Sci. Appl. Sci. Conf. Ser., Vol. 2, No. 1, p. 403, 2017.

[6] U. Nurajizah, S. Windyariani, and S. Setiono, "Improving students' metacognitive awareness through implementing learning journal," J. Pendidik. Biol. Indones., Vol. 4, No. 2, pp. 105-112, 2018.

[7] Y. Pantiwati and Husamah, "Self and peer assessments in active learning model to increase metacognitive awareness and cognitive abilities," Int. J. Instr., Vol. 10, No. 4, pp. 185-202, 2017, doi: 10.12973/iji.2017.10411a.

[8] I. Hindun, N. Nurwidodo, and A. G. C. Wicaksono, "Metacognitive awareness components of high-academic ability students in biology hybrid learning: Profile and correlation," JPBI (Jurnal Pendidik. Biol. Indones., Vol. 6, No. 1, pp. 31-38, 2020.

[9] M. A. Tiro, A. S. Ahmar, Penelitian Eksperimen, Merancang, Melaksanakan, Dan Melaporkan. Makassar: Adira Publisher, 2014.

[10] L. Fitria, Jamaluddin, and I. P. Artayasa, "Analisis Hubungan antara Kesadaran Metakognitif dengan Hasil Belajar Matematika dan IPA Siswa SMA di Kota Mataram Lia Fitria, Jamaluddin, I Putu Artayasa Program Studi Pendidikan Biologi, FKIP Universitas Mataram Corresponding Aut," J. Kependidikan, Vol. 6, No. 1, pp. $147-155,2020$

[11] E. F. Hamsyah, "Pengaruh strategi pembelajaran what's my line terhadap kesadaran metakognitif siswa," Chem. J. Ilm. Kim. dan Pendidik. Kim., 2019.

[12] D. Safitri, S. Bachtiar, and W. Y. Rukman, "Students ' Cognitive Achievement , Critical Thinking Skills , and Metacognitive," Eur. J. Educ. Stud., vol. 5, no. 4, pp. 248-258, 2018. 